\title{
Hubungan antara Pengetahuan, Sikap, dan Perilaku terhadap Pemeliharaan Kebersihan Gigi dan Mulut dengan Status Kesehatan Periodontal Pra Lansia di Posbindu Kecamatan Indihiang Kota Tasikmalaya
}

\author{
Culia Rahayu*, Sri Widiati**, dan Niken Widyanti** \\ * Politeknik Kesehatan Kemenkes Tasikmalaya \\ **Fakultas Kedokteran Gigi Universitas Gadjah Mada \\ * Jalan Cilolohan, Tasikmalaya, Kota Tasikmalaya, Jawa Barat, Indonesia 46115; e-mail: culiarahayu@yahoo.com
}

\begin{abstract}
ABSTRAK
Proses penuaan merupakan salah satu faktor sistemik yang mempengaruhi respon tubuh terhadap terjadinya penyakit periodontal. Penelitian ini bertujuan untuk mengetahui hubungan antara pengetahuan, sikap dan perilaku terhadap pemeliharaan kebersihan gigi dan mulut dengan status kesehatan periodontal pra lansia. Penelitian ini merupakan penelitian non eksperimental, dengan rancangan cross sectional. Subjek penelitian berjumlah 225 orang pra lansia dari 9 Posbindu di Kecamatan Indihiang Tasikmalaya, yang diambil dengan cara purposive sampling. Variabel pengaruh terdiri dari pengetahuan, sikap dan perilaku terhadap pemeliharaan kebersihan gigi dan mulut. Variabel pengetahuan diukur menggunakan kuesioner tertutup dengan pilihan jawaban benar atau salah. Variabel sikap dan perilaku diukur menggunakan kuesioner dibuat menurut skala Likert. Kuesioner telah diuji validitas (koefisien korelasi $\geq 0,30$ ) dan uji reliabilitas (alpha cronbach $>0,60$ ). Variabel terpengaruh adalah status kesehatan periodontal yang diukur menggunakan indeks CPITN. Analisa data menggunakan analisis korelasi dan regresi berganda. Hasil analisis regresi berganda menunjukkan bahwa variabel pengetahuan, sikap dan perilaku terhadap pemeliharaan kebersihan gigi dan mulut mempunyai hubungan signifikan terhadap status kesehatan periodontal $(F=30,681$ dan $p=0,001)$, dan memberikan kontribusi pengaruh sebesar $29,4 \%\left(R^{2}=0,294\right)$ terhadap status kesehatan periodontal. Perilaku terhadap pemeliharaan kebersihan gigi dan mulut memberikan kontribusi pengaruh paling besar terhadap status kesehatan periodontal yaitu sebesar $6,9 \%$. Kesimpulan dari penelitian ini adalah semakin baik pengetahuan, sikap dan perilaku terhadap pemeliharaan kebersihan gigi dan mulut, semakin baik status kesehatan periodontal pra lansia. Perilaku terhadap pemeliharaan kebersihan gigi dan mulut memberikan kontribusi pengaruh paling besar terhadap status kesehatan periodontal pra lansia.
\end{abstract}

Maj Ked Gi. Juni 2014; 21(1): 27 - 32.

Kata kunci: Pengetahuan, sikap, perilaku, status kesehatan periodontal, pra lansia.

ABSTRACT: Correlation Between Knowledge, Attitude and Behaviour on Oral Hygiene Maintenance with Periodontal Health Status of Pre Elderly at Posbindu of Sub-District Indihiang Tasikmalaya. Aging process is one of the systemic factors that influence the host response towards the occurrence of periodontal disease. The purpose of this study was to find out the correlation between knowledge, attitude, and behavior on oral hygiene maintenance with periodontal health status of pre elderly. Two hundred twenty-five pre elderly chosen purposively from 9 Posbindu of Sub-district Indihiang Tasikmalaya were used as a sample of non-experimental study with cross-sectional design. The independent variables were: knowledge, attitude and behavior on oral hygiene maintenance. Experience variable was measured in closed questionnaire with multiple-choice answers: true or false. Attitude and behavior variables were measured using a questionnaire with Likert scale. The results of the validity and reliability test show that correlation coefficient and alpha cronbachis $\geq 0,30$ and $>0,60$ respectively. CPITN index was used to measure dependent variable (periodontal health status). Correlation analysis and multiple regressions were used for data analysis. The result of multiple regression analysis shows that variables of knowledge, attitude and behavior on oral hygiene maintenance have a very significant correlation between periodontal health status $(F=30,681$ and $p=0,001)$ and gives an influence contribution of $29,4 \%(R 2=0,294)$ on periodontal health status. Behavior on oral hygiene maintenance gives the greatest influence contribution on periodontal health status as much as 6,9\%. Conclusions: The better of knowledge, attitude and behavior on oral hygiene maintenance lead to the better periodontal health status of pre elderly. The action on oral hygiene maintenance gives the biggest influence contribution on periodontal health status of pre elderly.

Maj Ked Gi. Juni 2014; 21(1): 27 - 32.

Keywords: Knowledge, attitude, behavior, periodontal health status, pre elderly 


\section{PENDAHULUAN}

Hasil Riset Kesehatan Dasar 2007 menunjukkan penyakit karies dan jaringan periodontal mempunyai prevalensi cukup tinggi di masyarakat yaitu sebesar $23,1 \%{ }^{1}$ Penyakit periodontal dapat menjadi penyebab utama dari tanggalnya gigi pada populasi dewasa. ${ }^{2}$ Penyebab utama penyakit periodontal adalah mikroorganisme yang berkolonisasi di permukaan gigi (plak bakteri dan produk-produk yang dihasilkannya). Selain penyebab utama, terdapat faktor-faktor risiko terjadinya perubahan pada jaringan periodontal antara lain: faktor lokal yang memudahkan retensi plak dan faktor sistemik yang mempengaruhi respon tubuh terhadap bakteri. ${ }^{3,4}$ Beberapa kelainan sistemik dapat berpengaruh buruk terhadap jaringan periodontal, tetapi faktor sistemik semata tanpa adanya plak bakteri tidak dapat menjadi pencetus terjadinya penyakit periodontal. ${ }^{3}$

Hasil penelitian pada lansia di Kecamatan Serpong Jakarta menunjukkan pengetahuan, sikap, dan perilaku pemeliharaan kesehatan gigi dan mulut masih kurang. Hasil pemeriksaan intra oral menunjukkan prevalensi karies sebesar $100 \%$, sedangkan prevalensi penyakit periodontal $97,18 \% .{ }^{5}$ Pengetahuan atau kognitif merupakan domain yang sangat penting untuk terbentuknya perilaku. Kurangnya pengetahuan mengenai kesehatan gigi merupakan faktor predisposisi dari perilaku kesehatan yang mengarah kepada timbulnya penyakit. ${ }^{6}$ Perilaku yang didasari oleh pengetahuan, kesadaran dan sikap positif lebih langgeng. Sebaliknya apabila perilaku tidak didasari pengetahuan dan kesadaran maka perilaku tidak akan berlangsung lama. ${ }^{7}$

Salah satu faktor utama yang mempengaruhi kesehatan gigi dan mulut penduduk di negara berkembang adalah sikap dan perilaku. Sikap dikatakan sebagai respon evaluatif, yang hanya akan timbul apabila individu dihadapkan pada stimulus yang menghendaki adanya reaksi. ${ }^{8}$ Sikap dapat merupakan suatu pengetahuan, tetapi yang disertai kecenderungan untuk bertindak sesuai dengan pengetahuan itu. ${ }^{9}$

Perilaku kesehatan gigi meliputi pengetahuan, sikap dan tindakan yang berkaitan dengan konsep sehat dan sakit gigi serta upaya pencegahannya.
Konsep kesehatan gigi adalah gigi dan semua jaringan yang ada di dalam mulut, termasuk gusi dan jaringan sekitarnya. ${ }^{6}$

Penelitian sebelumnya menunjuk kan status kesehatan gigi dan mulut 30 orang pra lansia di Posbindu Kecamatan Indihiang Kota Tasikmalaya menunjukkan rerata OHI-S 2,49 (kriteria sedang), yang mengalami gingivitis sebanyak $70 \%$, sedangkan perilaku menyikat gigi rerata 2 kali sehari pada waktu mandi pagi dan mandi sore, yang mempunyai keluhan pada gigi sebagian besar $(66,6 \%)$ mencari pengobatan sendiri dengan membeli obat diwarung.

Tujuan penelitian ini untuk mengetahui hubungan antara pengetahuan, sikap dan perilaku terhadap pemeliharaan kebersihan gigi dan mulut dengan status kesehatan periodontal pra lansia di Posbindu Kecamatan Indihiang Kota Tasikmalaya.

\section{METODE PENELITIAN}

Penelitian ini merupakan penelitian observasional, dengan rancangan crosssectional. ${ }^{10}$ Subjek penelitian berjumlah 225 pra lansia dari 9 Posbindu Kecamatan Indihiang Kota Tasikmalaya, pengambilan sampel dengan teknik purposive sampling, dengan kriteria inklusi: usia 45-59 tahun, bersedia dijadikan sampel penelitian, tidak mempunyai penyakit diabetes mellitus, bisa membaca dan menulis, mempunyai gigi indeks atau gigi yang bisa diperiksa. Penelitian ini telah mendapatkan persetujuan (informed concent) dari subjek penelitian.

Variabel pengaruh dalam penelitian ini adalah pengetahuan, sikap dan perilaku terhadap pemeliharaan kebersihan gigi dan mulut. Variabel terpengaruh adalah status kesehatan periodontal pra lansia di Posbindu Kecamatan Indihiang Kota Tasikmalaya.

Pengetahuan diukur menggunakan kuesioner tertutup dengan pilihan jawaban benar atau salah. Sikap dan perilaku terhadap pemeliharaan kebersihan gigi dan mulut diukur menggunakan kuesioner dibuat menurut skala Likert. Kuesioner telah diuji validitas pada 30 orang pra lansia (koefisien korelasi $\geq 0,30$ ) dan uji reliabilitas (acronbach $>0,60$ )..$^{11,12}$ Pengukuran status 
kesehatan periodontal pra lansia menggunakan indeks CPITN.${ }^{13}$ Gigi yang diperiksa adalah :

\begin{tabular}{lll}
\hline 17.16 & 11 & 26.27 \\
\hline 47.46 & 31 & 36.37 \\
\hline
\end{tabular}

Permukaan gigi yang diperiksa dari distal ke mesial baik permukaan labial/ bukal, lingual/ palatal. ${ }^{13}$ Penilaian gigi indeks menggunakan periodontal probe dengan kriteria sebagai berikut: 0 =sehat; $1=$ perdarahan; $2=$ karang gigi; $3=$ poket dangkal $(4-5 \mathrm{~mm}) ; 4=$ poket dalam $(\geq 6 \mathrm{~mm}) \cdot{ }^{13}$ Penelitian ini telah mendapatkan ethical clearance dari Komite Etik Penelitian Kesehatan Fakultas Kedokteran Gigi Universitas Gadjah Mada.

Data penelitian dianalisis dengan menggunakan análisis korelasi Product Moment dan regresi berganda $(p=0,001)$.

\section{HASIL PENELITIAN}

Sebagian besar $(49,78 \%)$ responden pada penelitian ini berumur 45-49 tahun dan jenis kelamin responden mayoritas perempuan $(85,33 \%)$.

Tabel 1. Distribusi Status Kesehatan Periodontal pada Responden yang Berkunjung ke Posbindu Kecamatan Indihiang $(n=225)$

\begin{tabular}{lcc}
\hline Kategori & $\begin{array}{c}\text { Frekuensi } \\
\text { (n) }\end{array}$ & $\begin{array}{c}\text { Persentase } \\
\text { (\%) }\end{array}$ \\
\hline Sehat & 1 & 0,44 \\
Perdarahan & 10 & 4,44 \\
Karang gigi & 119 & 52,89 \\
Poket dangkal & 94 & 41,79 \\
Poket dalam & 1 & 0,44 \\
\hline Jumlah & 225 & 100,00 \\
\hline
\end{tabular}

Tabel 1 mayoritas responden memiliki karang gigi $(52,89 \%)$, poket dangkal sebesar $41,79 \%$. Responden yang dinyatakan sehat hanya sebesar $0,44 \%$. Mayoritas responden $(88,89 \%)$ memiliki pengetahuan tentang pemeliharaan kebersihan gigi dan mulut dengan kategori baik. Sebagian besar dari responden tersebut memiliki karang gigi $(50,68 \%)$. Responden dengan status periodontal sehat $0,44 \%$ memiliki pengetahuan tentang pemeliharaan kebersihan gigi dan mulut kategori baik (Tabel 2).

Berdasarkan Tabel 3 mayoritas responden memiliki sikap terhadap pemeliharaan kebersihan gigi dan mulut dengan kategori cukup (78,22\%). Sebagian besar dari responden tersebut memiliki poket dangkal $(38,22 \%)$. Responden dengan status periodontal sehat $0,44 \%$ memiliki sikap terhadap pemeliharaan kebersihan gigi dan mulut kategori baik.

BerdasarkanTabel 4 hampir seluruh responden $(98,67 \%)$ memiliki perilaku terhadap pemeliharaan kebersihan gigi dan mulut kategori cukup. Sebagian besar dari responden tersebut $(52,90 \%)$ memiliki karang gigi. Satu-satunya responden dengan status periodontal sehat memiliki perilaku terhadap pemeliharaan kebersihan gigi dan mulut dengan kategori baik.

Hasil analisis korelasi menunjukkan variabel pengetahuan, sikap, dan perilaku terhadap pemeliharaan kebersihan gigi dan mulut mempunyai korelasi positif dengan status kesehatan periodontal $(p=0,001)$.

Tabel 3. Distribusi Responden berdasarkan Sikap terhadap Pemeliharaan Kebersihan Gigi dan Mulut dan Status Kesehatan Periodontal $(n=225)$

\begin{tabular}{|c|c|c|c|c|c|c|c|c|c|}
\hline \multirow{3}{*}{$\begin{array}{l}\text { Status } \\
\text { Periodontal }\end{array}$} & \multirow{3}{*}{ Kesehatan } & \multicolumn{6}{|c|}{ Sikap } & \multirow{2}{*}{\multicolumn{2}{|c|}{ Total }} \\
\hline & & \multicolumn{2}{|c|}{$\begin{array}{l}\text { Kurang } \\
(16-32)\end{array}$} & \multicolumn{2}{|c|}{$\begin{array}{l}\text { Cukup } \\
(33-48)\end{array}$} & \multicolumn{2}{|c|}{$\begin{array}{c}\text { Baik } \\
(49-64)\end{array}$} & & \\
\hline & & $n$ & $\%$ & $\mathbf{N}$ & $\%$ & $\mathrm{n}$ & $\%$ & $\mathbf{N}$ & $\%$ \\
\hline Sehat & & 0 & 0,00 & 0 & 0,00 & 1 & 0,44 & 1 & 0,44 \\
\hline Perdarahan & & 0 & 0,00 & 5 & 2,22 & 5 & 2,22 & 10 & 4,44 \\
\hline Karang gigi & & 0 & 0,00 & 84 & 37,34 & 35 & 15,56 & 119 & 52,90 \\
\hline Poket dangkal & & 0 & 0,00 & 86 & 38,22 & 8 & 3,56 & 94 & 41,78 \\
\hline Poket dalam & & 0 & 0,00 & 1 & 0,44 & 0 & 0,00 & 1 & 0,44 \\
\hline Total & & 0 & 0,00 & 176 & 78,22 & 49 & 21,78 & 225 & 100,00 \\
\hline
\end{tabular}


Tabel 4. Distribusi Responden Berdasarkan Perilaku terhadap Pemeliharaan Kebersihan Gigi dan Mulut dan Status Kesehatan Periodontal $(n=225)$

\begin{tabular}{|c|c|c|c|c|c|c|c|c|}
\hline \multirow{4}{*}{$\begin{array}{l}\text { Status Kesehatan } \\
\text { Periodontal }\end{array}$} & \multicolumn{7}{|c|}{ Perilaku } & \multirow{4}{*}{$\begin{array}{c}\text { Total } \\
\% \\
\end{array}$} \\
\hline & \multirow{2}{*}{\multicolumn{2}{|c|}{$\begin{array}{l}\text { Kurang } \\
(11-22)\end{array}$}} & \multirow{2}{*}{\multicolumn{2}{|c|}{$\begin{array}{l}\text { Cukup } \\
(23-33)\end{array}$}} & \multirow{2}{*}{\multicolumn{3}{|c|}{$\begin{array}{c}\text { Baik } \\
(34-44)\end{array}$}} & \\
\hline & & & & & & & & \\
\hline & $n$ & $\%$ & $\mathbf{N}$ & $\%$ & $\mathbf{n}$ & $\%$ & $\mathbf{n}$ & \\
\hline Sehat & 0 & 0,00 & 0 & 0,00 & 1 & 0,44 & 1 & 0,44 \\
\hline Perdarahan & 0 & 0,00 & 10 & 4,44 & 0 & 0,00 & 10 & 4,44 \\
\hline Karang gigi & 0 & 0,00 & 119 & 52,90 & 0 & 0,00 & 119 & 52,90 \\
\hline Poket dangkal & 2 & 0,89 & 92 & 40,89 & 0 & 0,00 & 94 & 41,78 \\
\hline Poket dalam & 0 & 0,00 & 1 & 0,44 & 0 & 0,00 & 1 & 0,44 \\
\hline Total & 2 & 0,89 & 222 & 98,67 & 1 & 0,44 & 225 & 100,0 \\
\hline
\end{tabular}

Tabel 5. Hasil Analisis Korelasi antara Variabel Bebas dan Variabel Terikat (Status Kesehatan Periodontal)

\begin{tabular}{llcc}
\hline No & Variabel Bebas & Koefisien Korelasi $\left(\mathbf{r}_{\mathbf{x y}}\right)$ & $\boldsymbol{p}$-Value \\
\hline 1. & Pengetahuan & 0,422 & 0,001 \\
2. & Sikap & 0,372 & 0,001 \\
3. & Perilaku & 0,446 & 0,001 \\
\hline
\end{tabular}

Keterangan: *) signifikansi pada $\alpha 5 \%$

Tabel 6. Hasil Analisis Regresi Berganda

\begin{tabular}{|c|c|c|c|c|}
\hline \multirow[b]{2}{*}{ Variabel Bebas } & \multirow[b]{2}{*}{ Koefisien Beta } & \multicolumn{2}{|l|}{ Standardized } & \multirow{2}{*}{$\begin{array}{l}\text { sig. } \\
\text { (p-Value) }\end{array}$} \\
\hline & & $\begin{array}{l}\text { Coefficients } \\
\text { Beta }\end{array}$ & $\mathbf{t}_{\text {hitung }}$ & \\
\hline Konstanta & $-3,010$ & -- & -- & -- \\
\hline Pengetahuan & 0,118 & 0,250 & 3,940 & 0,000 \\
\hline Sikap & 0,039 & 0,189 & 3,034 & 0,003 \\
\hline Perilaku & 0,068 & 0,265 & 4,032 & 0,000 \\
\hline$\overline{R^{2}}$ & \multicolumn{4}{|c|}{$=0,294$} \\
\hline $\mathrm{F}_{\text {hitung }}$ & \multicolumn{4}{|c|}{$=30,681$} \\
\hline Sig. ( $p$-Value) & \multicolumn{4}{|c|}{$=0,001$} \\
\hline
\end{tabular}

Berdasarkan analisis regresi berganda menunjukkan semua variabel bebas pengetahuan, sikap, dan perilaku terhadap pemeliharaan kebersihan gigi dan mulut mempunyai pengaruh signifikan terhadap status kesehatan periodontal $(p=0,001)$.

Hasil analisis regresi berganda diperoleh koefisien determinasi $\left(R^{2}\right)$ sebesar 0,294 , hal ini menunjukkan secara statistik variabel pengetahuan, sikap, dan perilaku terhadap pemeliharaan kebersihan gigi dan mulut memberi konstribusi terhadap status kesehatan periodontal pra lansia di Posbindu Kecamatan Indihiang Kota Tasikmalaya sebesar $29,4 \%$ dan selebihnya $(70,6 \%)$ ditentukan oleh faktor lain di luar penelitian ini.

Hasil analisis Partial Eta Squared menunjukkan bahwa variabel perilaku terhadap pemeliharaan kebersihan gigi dan mulut memberikan kontribusi pengaruh paling besar terhadap status kesehatan periodontal dengan memberikan sumbangan sebesar $6,9 \%$, disusul variabel pengetahuan sebesar $6,6 \%$, dan sikap sebesar $4,0 \%$. 


\section{PEMBAHASAN}

Berdasarkan analisis multi variat variabel pengetahuan, sikap, dan perilaku terhadap pemeliharaan kebersihan gigi dan mulut berpengaruh signifikan terhadap status kesehatan periodontal pra lansia $(p=0,001)$.

Kontribusi positif pengetahuan tentang pemeliharaan kebersihan gigi dan mulut terhadap status kesehatan periodontal dilihat dari nilai partial eta squared 0,066 , artinya variabel pengetahuan tentang pemeliharaan kebersihan gigi dan mulut memberikan kontribusi pengaruh sebesar $6,6 \%$. Hasil penelitian menunjukkan sebesar $50,68 \%$ responden memiliki karang gigi dengan kategori pengetahuan baik. Data deskriptif ini menunjukkan walaupun pra lansia berpengetahuan baik, tetapi pengetahuan saja tidak cukup untuk terbentuknya perilaku. Kemungkinan pra lansia memiliki tahap pengetahuan paling rendah yaitu "tahu" (hanya mengingat suatu objek) tidak sampai tahap pengetahuan paling tinggi yaitu "evaluasi" (kemampuan melakukan penilaian terhadap objek, misalnya menilai kondisi kesehatan gusinya pada saat tertentu). ${ }^{6}$

Perilaku kesehatan dipengaruhi oleh faktor internal meliputi pengetahuan, persepsi, emosi, motivasi, sedangkan faktor eksternal meliputi lingkungan fisik maupun non fisik. ${ }^{7}$ Pengetahuan berkaitan erat dengan pendidikan, mayoritas pra lansia berpendidikan tamat Sekolah Dasar kemungkinan kurang motivasi atau kemauan dan kurang menyadari pentingnya pemeliharaan kebersihan gigi dan mulut, menganggap penyakit gigi merupakan penyakit ringan.

Penelitian di Finlandia dan Amerika yang sejalan dengan penelitian ini, menunjukkan bahwa pengetahuan, sikap dan tindakan berpengaruh terhadap frekuensi menyikat gigi, kebersihan gigi dan mulut, dan periodontitis. ${ }^{14}$ Pengetahuan atau kognitif merupakan ranah yang sangat penting untuk terbentuknya perilaku seseorang. Pengetahuan kesehatan gigi akan mendasari sikap yang mempengaruhi perilaku seseorang dalam memelihara kebersihan gigi dan mulut. ${ }^{6}$

Kontribusi positif sikap terhadap status kesehatan periodontal diketahui dari nilai partial eta squared 0,04 , artinya variabel sikap terhadap pemeliharaankebersihangigidan mulutmemberikan kontribusi pengaruh sebesar $4,0 \%$. Sikap pra lansia terhadap pemeliharaan kebersihan gigi dan mulut dengan kategori cukup sebesar $78,22 \%$. Sebagian besar pra lansia mengalami poket dangkal $(38,22 \%)$, data ini menunjukkan bahwa sikap yang cukup pada pra lansia belum tentu disertai dengan perilaku yang baik dalam memelihara kebersihan gigi dan mulut. Sikap merupakan kecenderungan yang belum disertai tindakan nyata terhadap pemeliharaan kebersihan gigi dan mulut. ${ }^{6}$ Mann menyatakan bahwa sekalipun diasumsikan sikap merupakan predisposisi evaluatif yang banyak menentukan bagaimana individu bertindak, tetapi sikap dan tindakan nyata seringkali jauh berbeda. Hal ini dikarenakan tindakan nyata tidak hanya ditentukan oleh sikap semata, tetapi oleh berbagai faktor eksternal lainnya. ${ }^{15}$

Hasil penelitian Wiyatini ${ }^{16}$ yang sejalan dengan penelitian ini, menunjukkan pada usia 45 tahun atau lebih yang memiliki sikap kurang dalam pencegahan penyakit gigi menunjukkan prevalensi periodontitis lebih tinggi daripada yang memiliki sikap baik. Sikap merupakan suatu evaluasi yang positif dan negatif, serta melibatkan emosional seseorang dalam menanggapi objek sosial, artinya bila hasilnya positif maka seseorang akan cenderung mendekati objek, dan sebaliknya bila sikapnya negatif cenderung menjauhi objek. ${ }^{6}$

Hasil analisis menunjukkan kontribusi positif perilaku pemeliharaan kebersihan gigi dan mulut terhadap status kesehatan periodontal diketahui dari nilai partial eta squared 0,069 , artinya variabel perilaku terhadap pemeliharaan kebersihan gigi dan mulut memberikan kontribusi pengaruh sebesar $6,9 \%$. Hasil penelitian menunjukkan mayoritas pra lansia memiliki karang gigi sebesar $52,90 \%$ dengan perilaku terhadap pemeliharaan kebersihan gigi kategori cukup, hal ini kemungkinan disebabkan perilaku pra lansia terhadap pemeliharaan kebersihan gigi dan mulut belum tepat dan benar, misalnya menyikat gigi dilakukan pada saat mandi pagi dan sore, cara menyikat gigi tidak benar. Mayoritas pra lansia apabila ada keluhan sakit gigi cukup ditangani sendiri dengan membeli obat di warung, walaupun memeriksakan giginya dalam keadaan sudah tidak bisa ditangani. Mayoritas pra lansia adalah ibu rumah tangga dan buruh tani 
kemungkinan sumber dana mempengaruhi perilaku pemanfaatan pelayanan kesehatan, sehingga pra lansia tidak memeriksakan giginya.

Penelitian Sriyono ${ }^{17}$ yang sejalan dengan penelitian ini menunjukkan bahwa terdapat hubungan antara perilaku terhadap pemeliharaan kesehatan gigi dan mulut dengan gingivitis pada lansia. Perilaku kesehatan merupakan salah satu faktor yang mempengaruhi status kesehatan seseorang. Penyebab seseorang berperilaku sehat atau tidak berperilaku sehat adalah pengetahuan, perilaku kesehatan dari orang lain yang menjadi panutan, sumber daya (fasilitas kesehatan, uang, waktu, tenaga, jarak ke fasilitas kesehatan) dan kebudayaan. ${ }^{6}$

\section{KESIMPULAN}

Kesimpulan dari penelitian ini adalah: Semakin baik pengetahuan, sikap, dan perilaku terhadap pemeliharaan kebersihan gigi dan mulut, semakin baik status kesehatan periodontal pra lansia di Posbindu Kecamatan Indihiang Kota Tasikmalaya. Perilaku terhadap pemeliharaan kebersihan gigi dan mulut memberikan kontribusi pengaruh paling besar terhadap status kesehatan periodontal pra lansia di Posbindu Kecamatan Indihiang Kota Tasikmalaya.

\section{DAFTAR PUSTAKA}

1. Kemenkes, Rencana program pelayanan kesehatan gigi dan mulut 2011-2025, Jakarta: Subdit Pelayanan Kesehatan Gigi; 2012. h. 2-5.

2. Smith D, Seymour R. Penyakit periodontal dan perawatannya pada lansia. Barnes IE, Walls $A$. dalam perawatan gigi terpadu untuk lansia (gerodontology). Jakarta: EGC; 2006. h. 82.

3. Rees T. Faktor penyerta sistemik. Fedi PF, Vernino A, Gray JL. dalam: Silabus periodonti, Jakarta: EGC; 2005. h. 21-22.

4. Vernino A. Etiologi penyakit periodontal, Fedi PF, Vernino A, dan Gray JL. dalam: Silabus periodonti. Jakarta: EGC; 2005. h. 13.
5. Bahar A. Masalah kesehatan gigi lansia di lengkong gudang dan serpong serta saran penanggulangannya melalui peran serta kader kesehatan FKG UI

6. Jakarta. Jurnal Kedokteran Gigi. 2000; 7: 311-317.

7. Budiharto. Pengantar ilmu perilaku kesehatan dan pendidikan kesehatan gigi. Jakarta: EGC; 2010. h. 17-21.

8. Notoatmodjo. Promosi kesehatan dan ilmu perilaku. Jakarta: Rineka Cipta, 2007. h. 140.

9. Sobur A. Psikologi umum. Bandung: Pustaka Setia; 2011. h. 446-447.

10. Gerungan WA. Psikologi sosial. Edisi ke-3. Bandung: Refika Aditama; 2009. h. 160-161.

11. Pratiknya AW. Dasar-dasar metodologi penelitian kedokteran dan kesehatan, Jakarta: Raja Grafindo Persada; 2010. h. 10-1

12. Singarimbun M, Effendi $S$. Metode penelitian survei, Jakarta: LP3ES; 2008. h. 122, 132137

13. Azwar S. Reliabilitas dan validitas. Edisi ke-3. Yogyakarta: Pustaka Pelajar Offset; 2011.

14. Sriyono. Pengantar ilmu kedokteran gigi pencegahan. Yogyakarta: Medika Fakultas Kedokteran Universitas Gadjah Mada; 2011. h. 49

15. Tjahja, Lely. Pengaruh faktor individu terhadap keradangan gusi di puskesmas dki jakarta tahun 2007. Media Penelitian dan Pengembang Kesehatan. 2009; XIX: 49-62.

16. Azwar S. Sikap manusia, teori dan pengukurannya. Edisi ke-2. Yogyakarta: Pustaka Pelajar Offset; 2011: 21.

17. Wiyatini T. Faktor-faktor lokal dalam mulut dan perilaku pencegahan yang berhubungan dengan periodontitis, Semarang, Universitas Diponegoro, Semarang. Jurnal Epidemiologi. 2009.

18. Sriyono NW. Correlation age, attitude, and dental care behaviour with oral health status of institutionalized elderly in yogyakarta indonesia, Hongkong. Hongkong Dental Journal. 2005; 2: 30-35. 